\title{
Spectroscopic and thermal characterization of alternative model biomembranes from shed skins of Bothrops jararaca and Spilotis pullatus
}

\author{
André Rolim Baby ${ }^{1}$, Áurea Cristina Lemos Lacerda ${ }^{1}$, Fernanda Daud Sarruf ${ }^{1}$, Claudinéia \\ Aparecida Sales de Oliveira Pinto ${ }^{1}$, Vladi Olga Consiglieri ${ }^{1}$, Cristina Helena dos Reis Serra ${ }^{1}$, Maria \\ Valéria Robles Velasco ${ }^{1}$, Yoshio Kawano ${ }^{2}$, Telma Mary Kaneko ${ }^{1}$
}

${ }^{1}$ Department of Pharmacy, Faculty of Pharmaceutical Sciences, University of São Paulo

${ }^{2}$ Department of Fundamental Chemistry, Institute of Chemistry, University of São Paulo

\begin{abstract}
Recently, there has been an interest in the use of shed snake skin as alternative model biomembrane for human stratum corneum. This research work presented as objective the qualitative characterization of alternative model biomembranes from Bothrops jararaca and Spilotis pullatus by FT-Raman, PAS-FTIR and DSC. The employed biophysical techniques permitted the characterization of the biomembranes from shed snake skin of $B$. jararaca and $S$. pullatus by the identification of vibrational frequencies and endothermic transitions that are similar to those of the human stratum corneum.
\end{abstract}

Uniterms: Biomembrane/alternative models. Bothrops jararaca/skin/qualitative characterization. Spilotis pullatus/skin/qualitative characterization. Human stratum corneum/similars.

\begin{abstract}
Existe atualmente interesse no uso da muda de pele de cobra como modelos alternativos de biomembranas da pele humana. O presente trabalho apresentou como objetivo a caracterização qualitativa de modelos alternativos de biomembranas provenientes de mudas de pele de cobra da Bothrops jararaca e Spilotis pullatus por espectroscopia Raman (FT-Raman), espectroscopia fotoacústica no infravermelho (PASFTIR) e calorimetria exploratória diferencial (DSC). As técnicas biofísicas FT-Raman, PAS-FTIR e DSC permitiram caracterizar qualitativamente os modelos alternativos de biomembranas provenientes das mudas de pele de cobra da $B$. jararaca e $S$. pullatus e identificar freqüências vibracionais e transições endotérmicas similares ao estrato córneo humano.
\end{abstract}

Unitermos: Biomembranas/modelos alternativos. Bothrops jararaca/pele/caracterização qualitativa. Spilotis pullatus/pele/caracterização qualitativa. Estrato córneo humano/similares.

\section{INTRODUCTION}

The intact human skin is considered as a barrier against the penetration and permeation of agents such as particles, chemical substances, radiations and microorganisms (Williams, Barry, Edwards, 1994). It is of utmost importance for the survival of human beings, despite being an obstacle for the action of active substances applied over the skin (Kalia et al., 2004).

Cutaneous penetration and permeation of active

\footnotetext{
*Correspondence: A. R. Baby. Laboratório de Cosmetologia, Departamento de Farmácia, Faculdade de Ciências Farmacêuticas , Universidade de São Paulo, Av. Prof. Lineu Prestes, 580, Bl. 13/15 - Cidade Universitária. 05508-900 - São Paulo - SP, Brasil. E-mail: andrerb@usp.br
}

substances may be firstly limited by the epidermis, especially the stratum corneum (SC), due to its barrier function and to the fact that it is the first layer of contact with the outer side. The epidermis is divided into two portions: (1) the internal portion, formed by cells that are constantly proliferating; (2) the external portion, formed by the same cells that originate the SC after its keratinization and death (Moser et al., 2001).

Skin penetration studies using in vitro evaluation present advantages such as: economy, fast obtainment of results, control of the experimental conditions and the possibility to evaluate a larger number of replicates, among others. The ideal situation would be to use human skin as a model, but the lack of this material, the need to submit the 
experiment to an Ethics Committee, the storage difficulties and high cost, and the viability of this membrane model limit its usage (Baby et al., 2009; Schmook, Meingassner, Billich, 2001; Rigg, Barry, 1990).

As alternative biomembranes, experimentation animals' skin, synthetic membranes and three-dimensional cultures are used to experimentally simulate epidermis. There is interest in using shed snake skin in alternative models of human skin biomembranes, and researchers have been evaluating its applicability in penetration / permeation studies, obtaining favorable responses. Shed snake skin is composed by pure $\mathrm{SC}$ without viable epidermis and follicles (Rigg, Barry, 1990). It offers a barrier similar to human SC and can be obtained abundantly without the death of the animal. Shed snake skin can be easily stored and does not tend to be contaminated nor microbiologically degraded, as it does not present living tissues (Itoh et al., 1990; Baby et al., 2007; Baby et al., 2008a).

Shed snake skin have similarities with human SC, such as: (1) tissue thickness (human $\mathrm{SC}=13-15 \mu \mathrm{m}$; shed snake skin $=10-20 \mu \mathrm{m})$; (2) protein structure (keratin type $\alpha$ and $\beta$ ); and (3) lipid composition (human $\mathrm{SC}=2.0-6.5 \%$; shed snake skin $=$ approximately $6.0 \%$, involving the presence of cholesterol, free fatty acids, glycol ceramides and phospholipids, among others) (Rigg, Barry, 1990).

Various biophysical methods have been employed to study the morphology and dynamics of the SC, aiming to understand the correlation between its structure and function. Among these methods: X-ray diffraction, electron paramagnetic resonance, nuclear magnetic resonance, DSC (Differential Scanning Calorimetry), FT-Raman, and PAS-FTIR (Lafleur, 2001; Baby et al., 2006a; Baby et al., 2008b).

This research work aimed at characterizing qualitatively alternative models of biomembranes from Bothrops jararaca and Spilotis pullatus shed snake skin through FTRaman, PAS-FTIR and DSC. It is also worth to mention that the usage of shed snake skin as alternative model of biomembrane to study cutaneous permeation contemplates the aspect of Experimental Ethics in Animals and Human Beings, besides being ecologically correct.

\section{MATERIAL AND METHODS}

\section{Sample preparation}

Ventral portions of Bothrops jararaca and Spilotis pullatus shed snake skin, gently donated by Butantan Institute, São Paulo, were cut and washed in abundance with distilled water. The samples were immersed in distilled water for eight hours in order to hydrate. After samples' hydration, the excess of water was removed with smooth compression using quantitative filter paper (Baby et al., 2006b). The samples were kept between two microscopy laminas and maintained in a desiccator until the time of analysis with FT-Raman, PAS-FTIR and DSC.

\section{FT-Raman}

Raman Bruker ${ }^{\circledR}$ RFS 100/S Spectrometers with OPUS ${ }^{\circledR}$ software were used. The samples were put in the analytical compartment and 256 co-additions corresponding to the spectra between 3500 and $200 \mathrm{~cm}^{-1}$ were obtained. The conditions were the following: (1) laser potency: $250 \mathrm{~mW}$; (2) resolution: $4 \mathrm{~cm}^{-1}$; (3) slit: 7; and (4) gain: 4 (Baby et al., 2007; Baby et al., 2006b). Three replicates were used.

\section{PAS-FTIR}

The samples were adequately cut so as to fulfill the area of the photoacoustic cell in a model MTEC ${ }^{\circledR} 200$ spectrometer. In order to avoid the movement of the cell, the samples were covered by a metal device. Then, a flow of helium was used for $2 \mathrm{~min}$ to remove water and carbon dioxide molecules. After sealing the cells, vacuum was made in the spectrometer. The 64 co-additions were controlled using the Bomem ${ }^{\circledR}$ PCDA program, in the spectral range of $4000-400 \mathrm{~cm}^{-1}$. A rubber composite was used as standard. The experimental conditions were: (1) resolution: $4 \mathrm{~cm}^{-1}$; (2) slit: 10; (3) gain: 4; and (4) speed of the mobile mirror: $0.05 \mathrm{~cm} / \mathrm{s}$ (Baby et al., 2007; Baby et al., 2006a). The measurements were done using three replicates.

\section{DSC}

Samples of approximately $2.0 \mathrm{mg}$ were sealed in a semi-hermetic crucible and were submitted to the following conditions (Baby et al., 2006b) in the DSC 10 equipment: (1) initial temperature: $25.0^{\circ} \mathrm{C}$; (2) cooling ramp: $20.0^{\circ} \mathrm{C} / \mathrm{min}$ to $0{ }^{\circ} \mathrm{C}(3)$ isotherm: $5 \mathrm{~min}(4)$ heating ramp: $10.0^{\circ} \mathrm{C} / \mathrm{min}$ to $160^{\circ} \mathrm{C}(5)$ cooling ramp: $20.0^{\circ} \mathrm{C} / \mathrm{min}$ to $0{ }^{\circ} \mathrm{C}(6)$ isotherm: $5 \mathrm{~min}(7)$ heating ramp: $10.0^{\circ} \mathrm{C} / \mathrm{min}$ to $160^{\circ} \mathrm{C}$; and (8) final temperature: $25.0^{\circ} \mathrm{C}$ (Baby et al., 2006b).

The transition temperatures were determined considering the minimum values of the endothermic peaks observed in the heating curves. The DSC curves were built with the values of the heat flow as a function of the temperature. The measurements involved three replicates. 


\section{RESULTS AND DISCUSSION}

FT-Raman spectroscopy is useful to study biological materials, as water presents minimum interference, when compared, for instance, to infrared spectroscopy (Anigbogu et al., 1995; Casper et al., 2001). In the SC study, the vibrational frequencies of particular interest are: $\mathrm{C}-\mathrm{H}\left(3100-2700 \mathrm{~cm}^{-1}\right), \mathrm{C}=\mathrm{O}$ (around $1650 \mathrm{~cm}^{-1}$ - amide I) originated from the $\alpha$-keratin, $\mathrm{C}-\mathrm{N}\left(1274 \mathrm{~cm}^{-1}\right)$ and $\mathrm{N}-\mathrm{H}$ angular deformation of protein (amide III) (Anigbogu et al., 1995; Baby et al., 2008b; Diem, 1993).

Raman spectra of the SC samples of Bothrops jararaca and Spilotis pullatus shed snake skin (Figures 1 and 2 , respectively) presented spectral profiles similar to the ones described in the literature (Williams, Barry, Edwards, 1994). Characteristic vibrational spectral regions of the SC were observed, with intense signal bands between $3100-2700 \mathrm{~cm}^{-1}$, referring to distensions originated from the lipid carbonic chains (symmetric and non-symmetric $\mathrm{CH}_{3}$, symmetric and non-symmetric $\mathrm{CH}_{2}$ and $\mathrm{CH}$ ).

There was a band in the region between $1650-1672 \mathrm{~cm}^{-1}$, related to the distention of the $\mathrm{C}=\mathrm{O}$ of the $\alpha$-keratin's amide I and, possibly, $\beta$-keratin. Besides, there was a band in the region between $1450-1460 \mathrm{~cm}^{-1}$, probably originated from the angular deformation from $\mathrm{C}-\mathrm{H}$ to $\mathrm{CH}, \mathrm{CH}_{2}$ and $\mathrm{CH}_{3}$.

When comparing the Raman spectra from the SC of both species, there are similarities. However, the intensity of the signal appears to be greater for Spilotis pullatus, especially as far as the band between $3100-2700 \mathrm{~cm}^{-1}$ is concerned, what indicates differences in the biomembrane surface's morphology among these species.

Raman spectroscopy registers signals due to the spreading light that strikes on the sample's surface. Therefore, differences in signals' intensities are related to alterations in the sample's surface morphology caused by modifications in the molecular density per area unit of the

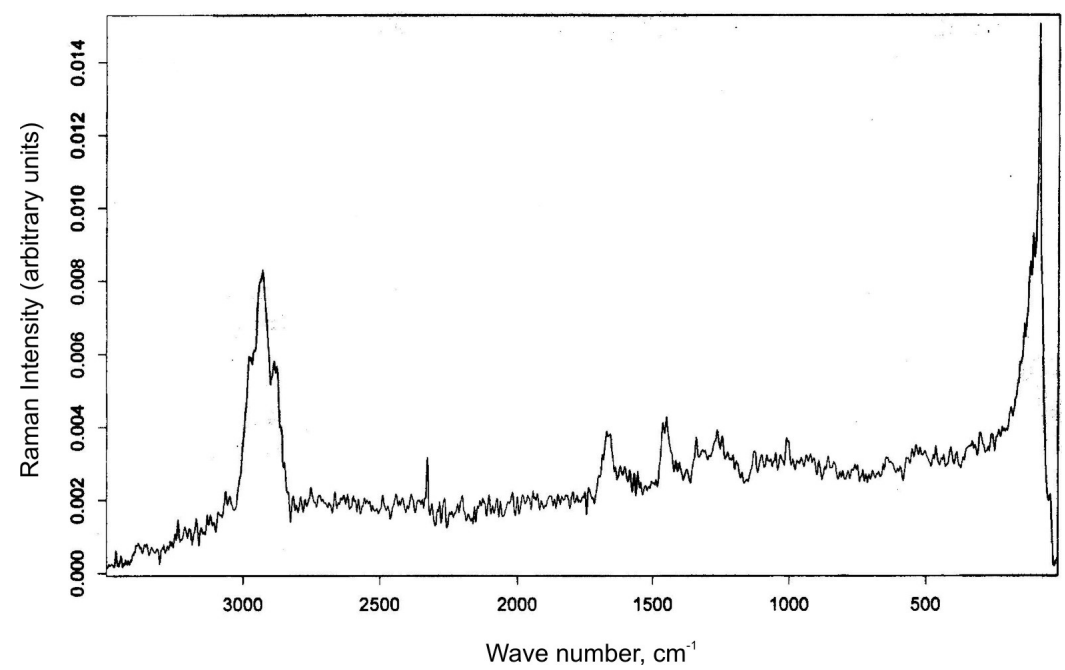

FIGURE 1 - FT-Raman spectral profile of the Bothrops jararaca biomembrane model.

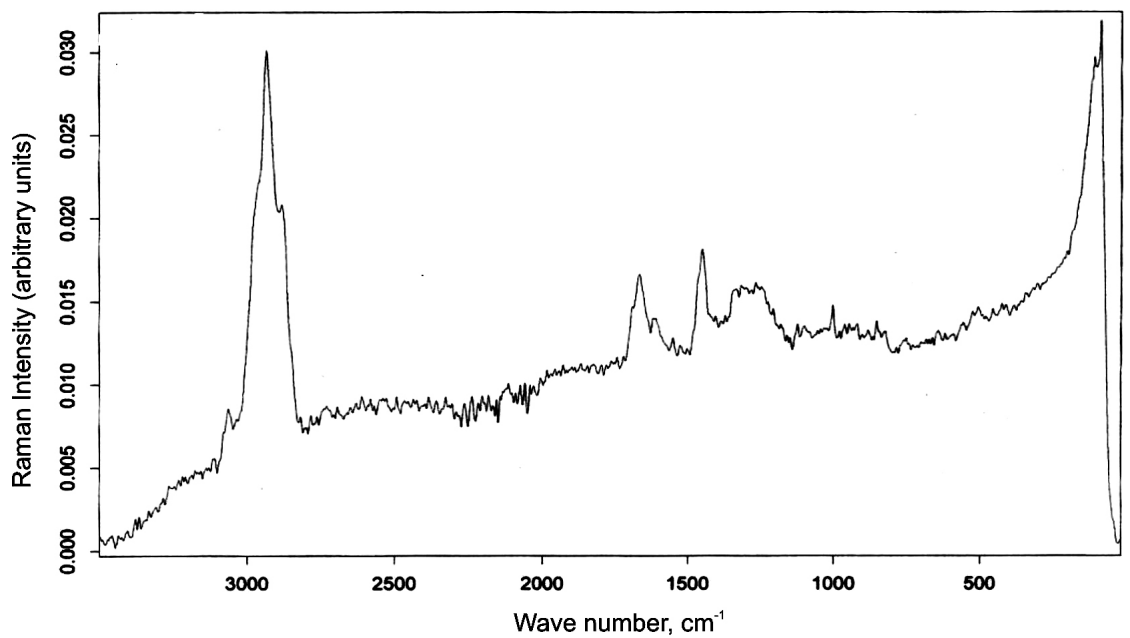

FIGURE 2 - FT-Raman spectral profile of the Spilotis pullatus biomembrane model. 
surface region involved in the spreading of light, and by alterations in its topography (Ingle, Crouch, 1988).

In Figures 3 and 4 (PAS-FTIR spectra), we can observe the typical profiles of the hydrated biological material, with bands in $1650 \mathrm{~cm}^{-1}(\mathrm{C}=\mathrm{O}$ distension of amide $\mathrm{I})$ and in $1550 \mathrm{~cm}^{-1}(\mathrm{C}-\mathrm{N}$ distension and $\mathrm{N}-\mathrm{H}$ deformation of amide II). In the band between $3600-3300 \mathrm{~cm}^{-1}$, we can observe the presence of water in the species' SC (Golden et al., 1986; Lin et al., 1992).

The usage of DSC enables the study of structure and organization of the SC though the observation of the characteristic temperatures of the endothermic events related to the lipid fraction, e.g. phase transitions, and to the protein fraction of biomembranes that involve dehydration and keratin denaturation phenomena (Lin, Duan, Lin, 1996).

The isolated human SC has four characteristic endothermic transitions. The phase transition of the lipid bilayer from crystalline to gel state is attributed to the temperature of $40{ }^{\circ} \mathrm{C}$. The phase transition of the lipid bilayer from lamellar gel to liquid state is attributed to the temperature of $75-85^{\circ} \mathrm{C}$. The transition that occurs at $105^{\circ} \mathrm{C}$ represents the dehydration and denaturation of the protein fraction of the SC and the presence of a certain amount of water in the sample is required for its detection by the technique (Baby et al., 2006b; Golden et al., 1986, Ashton et al., 1992; Leopold, Lipppold, 1995).

In the DSC curve from Bothrops jararaca shed skin (Figure 5), not all the lipids endothermic transition peaks were observed. However, a transition of small magnitude was observed at, approximately, $58^{\circ} \mathrm{C}$. The endothermic peak referring to the transition involving dehydration and keratin denaturation occurred clearly at $130{ }^{\circ} \mathrm{C}$.

Spilotis pullatus shed skin biomembrane presented a DSC curve similar to B. jararaca. The endothermic transi-

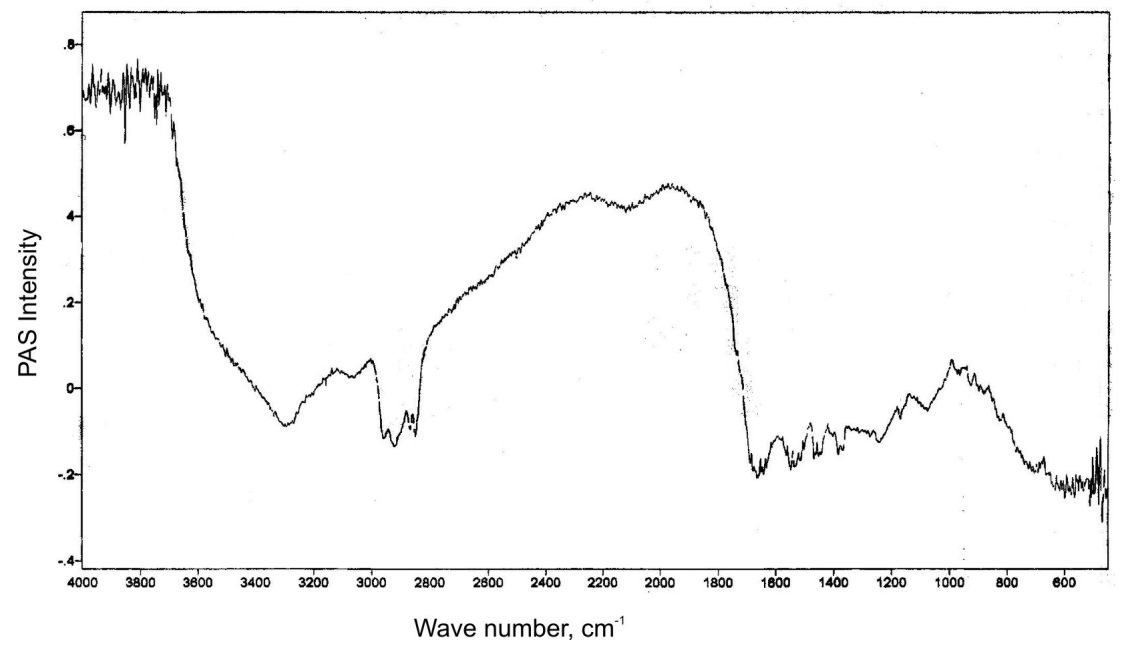

FIGURE 3 - PAS-FTIR spectral profile of the Bothrops jararaca biomembrane model.

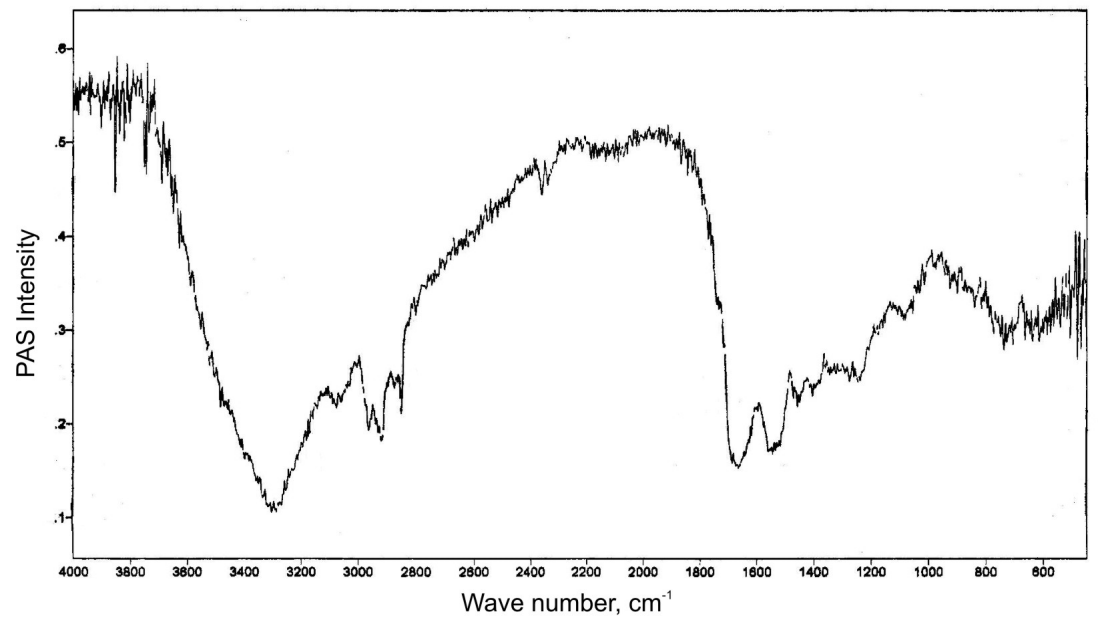

FIGURE 4 - PAS-FTIR spectral profile of the Spilotis pullatus biomembrane model. 


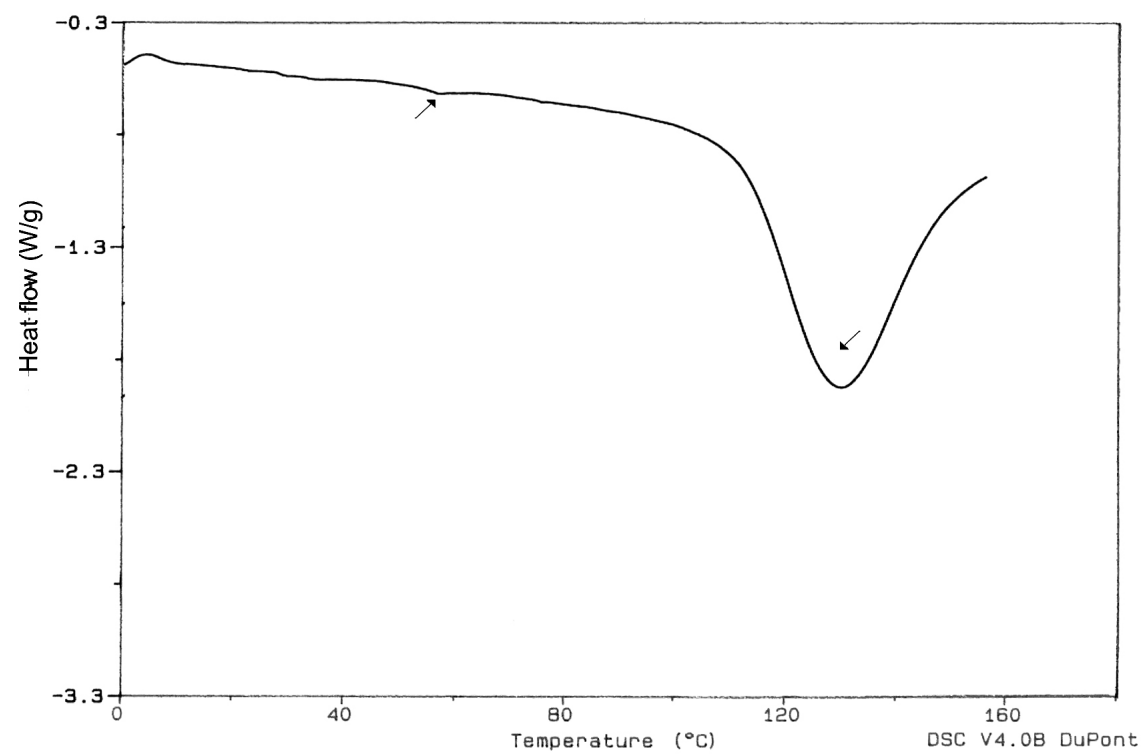

FIGURE 5 - DSC curve of the Bothrops jararaca biomembrane model.

tions related to lipids were of reduced intensity, observed at 38 and at $58^{\circ} \mathrm{C}$. The transition related to dehydration and denaturation of the protein fraction occurred at $129^{\circ} \mathrm{C}$.

\section{CONCLUSIONS}

The biophysical techniques FT-Raman, PAS-FTIR and DSC allowed the qualitative characterization of biomembranes alternative models from Bothrops jararaca and Spilotis pullatus shed snake skin, and the identification of the vibrational frequencies and endothermic transitions similar to those of the human SC.

\section{ACKNOWLEDGEMENTS}

The authors would like to thank CAPES, Butantan Institute, especially Dr. Wilson Fernandes and Dr. Otávio Azevedo Mercadante, and the dedicated reviewers of this research work.

\section{REFERENCES}

ANIGBOGU, A.N.C.; WILLIAMS, A.C.; BARRY, B.W.; EDWARDS, H.G.M. Fourier transform Raman spectroscopy of interactions between the penetration enhancer dimethyl sulfoxide and human stratum corneum. Int. J. Pharm., Amsterdam, v.125, n.2, p.265-282, 1995.

ASHTON, P.; WALTERS, K.A.; BRIAN, K.R.; HADGRAFT, J. Surfactant effects in percutaneous absorption I. effects on transdermal flux of methyl nicotinate. Int. J. Pharm., Amsterdam, v.87, n.1-3, p.261-264, 1992.
BABY,A.R.; HAROUTIOUNIAN-FILHO, C.A.; SARRUF, F.D.; PINTO, C.A.S.O.; KANEKO, T.M.; VELASCO, M.V.R. Influence of urea, isopropanol, and propylene glycol rutin in vitro release from cosmetic semisolid systems estimated by factorial design. Drug Dev. Ind. Pharm., New York, v.35, n.3, p.272-282, 2009.

BABY, A.R.; HAROUTIOUNIAN-FILHO, C.A.; SARRUF, F.D.; TAVANTE-JÚNIOR, C.R.; PINTO, C.A.S.O.;ZAGUE, V.; AREAAS, E.P.G.; KANEKO, T.M.; VELASCO, M.V.R. Estabilidade e estudo de penetração cutânea in vitro da rutina veiculada em uma emulsão cosmética através de um modelo de biomembrane alternativo. Rev. Bras. Cienc. Farm., São Paulo, v.44, n.2, p.233-248, $2008 \mathrm{a}$.

BABY, A.R.; LACERDA, A.C.L.; KAWANO, Y.; VELASCO, M.V.R.; KANEKO, T.M. PAS-FTIR and FT-Raman qualitative characterization of sodium dodecyl sulfate interaction with an alternative stratum corneum model membrane. Pharmazie, Eschborn, v.62, n.10, p.727-731, 2007.

BABY, A.R.; LACERDA, A.C.L.; KAWANO, Y.; VELASCO, M.V.R.; LOPES, P.S.; KANEKO, T.M. Spectroscopic studies of stratum corneum model membrane from Bothrops jararaca treated with cationic surfactant. Colloid. Surf. B Biointerfaces, Amsterdam, v.50, n.1, p.61-65, 2006a.

BABY, A.R.; LACERDA, A.C.L.; KAWANO, Y.; VELASCO, M.V.R.; LOPES, P.S.; KANEKO, T.M. Evaluation of the interaction of surfactants with stratum corneum model membrane from Bothrops jararaca by DSC. Int. J. Pharm., Amsterdam, v.317, n.1, p.7-9, 2006 b. 
BABY, A.R.; LACERDA, A.C.L.; PINTO, C.A.S.O.; LOPES, P.S.; VELASCO, M.V.R.; KANEKO, T.M. Métodos biofísicos empregados na análise do estrato córneo. Lat. Am. J. Pharm., Buenos Aires, v.27, n.1, p.124-130, 2008b.

CASPER, P.; LUCASSEN, G.W.; CARTER, E.A.; BRUINING, E.A.H.; PUPPEL, G.J. In vivo confocal Raman microspectroscopy of skin: noninvasive determination of molecular concentration profiles. J. Invest Dermatol., Baltimore, v.116, n.3, p.434-442, 2001.

DIEM, M. Biophysical applications of vibrational spectroscopy . In: _. . Introduction to modern vibrational spectroscopy. New York: John Wiley \& Sons, 1993. cap.8, p.205-235.

GOLDEN, G.M.; GUZEK, D.B.; HARRIS, R.R.; MCKIE, J.E.; POTTS, R. Lipid thermotropic transitions in human stratum corneum. J. Invest. Dermatol., Baltimore, v.86, n.3, p.255$259,1986$.

INGLE, J.D; CROUCH, S. Spectrochemical techniques on the horizon. In:__Spectrochemical Analysis. New Jersey: Prentice Hall, 1988. cap.17, p.525-541.

ITOH, T.; XIA, J.; MAGAVI, R.; NISHIHATA, T.; RYTTING, J.H. Use of shed snake skin as a model membrane for in vitro percutaneous penetration studies: comparison with human skin. Pharm. Res., New York, v.7, n.10, p.1042-1047, 1990.

KALIA, Y.N.; NAIK, A.; GARRISON, J.; GUY, R.H. Iontophoretic Drug Delivery. Adv. Drug Deliv. Rev., Amsterdam, v.56, n.5, p.619-658, 2004.

LEOPOLD, C.S.; LIPPPOLD, B.C. An attempt to clarify the mechanism of the penetration enhancing effects of lipophilic vehicles with differential scanning calorimetry (DSC). J. Pharm. Pharmacol., London, v.47, n.4, p.276-281, 1995.
LIN, S. Y.; HOU, S.J.; HSU, T.H.S.; YEH, F.L. Comparisons of different animal skins with human skin in drug percutaneous penetration studies. Methods Find. Exp. Clin. Pharmacol., Barcelona, v.14, n.8, p.645-654, 1992.

LIN, S.Y.; DUAN, K.J.; LIN, T.C. Microscopic FT-IR/DSC system used to simultaneously investigate the conversion process of protein structure in porcine stratum corneum after pretreatment with skin penetration enhancers. Methods Find. Exp. Clin. Pharmacol., Barcelona, v.18, n.3, p.175-181, 1996.

MOSER, K.; KRIWET, K.; NAIK, A.; KALIA, Y. N.; GUY, R.H. Passive skin penetration enhancement and its quantification in vitro. Eur. J. Phar. Biopharm., Amsterdam, v.52, n.2, p.103 - 112, 2001

PERCOT, A.; LAFLEUR, M. Direct observation of domains in model stratum corneum lipid mixtures by Raman microspectroscopy. Biophys. J., New York, v.81, n.4, p.2144-2153, 2001.

RIGG, P.C.; BARRY, B.W. Shed snake skin and hairless mouse skin as a model membrane for human skin during permeation studies. J. Invest. Dermatol., Baltimore, v.94, n.2, p.235-240, 1990.

SCHMOOK, F.P.; MEINGASSNER, J.G.; BILLICH, A. Comparison of human skin or epidermis models with human and animal skin in in-vitro percutaneous absorption. Int. J. Pharm., Amsterdam, v.215, n.1/2, p.51-56, 2001.

WILLIAMS, A.C.; BARRY, B.W.; EDWARDS, H.G.M. Comparison of Fourier Transform Raman spectra of mammalian and reptilian skin. Analyst, Cambridge, v.119, n.4, p.563-566, 1994.

Received for publication on $20^{\text {th }}$ February 2008 Accepted for publication on $13^{\text {th }}$ January 2009 